\title{
DETERMINATION OF MOLECULAR GENETIC MARKERS IN PROGNOSIS OF THE EFFECTIVENESS OF TREATMENT OF MALIGNANT INTRACEREBRAL BRAIN TUMORS
}

\author{
Oleksandr Glavatskyi \\ Department of Adjuvant Treatment of CNS Tumors \\ State Institution "Institute of Neurosurgery named after acad. A. P. Romodanov of NAMS of Ukraine" \\ 32 Platona Mayborody str., Kyiv, Ukraine, 04050 \\ oleksandr.glavatskyi@gmail.com \\ Irina Vasileva \\ Department of Neurobiochemistry \\ State Institution "Institute of Neurosurgery named after acad. A. P. Romodanov of NAMS of Ukraine" \\ 32 Platona Mayborody str., Kyiv, Ukraine, 04050 \\ vigvasileva@gmail.com

\section{Olena Galanta} \\ Department of Neurobiochemistry \\ State Institution "Institute of Neurosurgery named after acad. A. P. Romodanov of NAMS of Ukraine" \\ 32 Platona Mayborody str., Kyiv, Ukraine, 04050 \\ lenagalanta@gmail.com \\ Hennadii Khmelnytskyi \\ Department of Intracerebral Tumors \\ State Institution "Institute of Neurosurgery named after acad. A. P. Romodanov of NAMS of Ukraine" \\ 32 Platona Mayborody str., Kyiv, Ukraine, 04050 \\ kh31_g@hotmail.com \\ Irina Shuba \\ Department of Neurobiochemistry \\ State Institution "Institute of Neurosurgery named after acad. A. P. Romodanov of NAMS of Ukraine" \\ 32 Platona Mayborody str., Kyiv, Ukraine, 04050 \\ irina_shuba@ukr.net \\ Konstantin Kardash \\ Department of Neurosurgery \\ Odessa Regional Hospital \\ 26 Academician Zabolotniy str., Odessa, Ukraine, 65025 \\ kardash1970@yahoo.com \\ Oksana Zemskova \\ Department of Radioneurosurgery \\ State Institution "Institute of Neurosurgery named after acad. A. P. Romodanov of NAMS of Ukraine" \\ 32 Platona Mayborody str., Kyiv, Ukraine, 04050 \\ oxzemskova@gmail.com
}

\section{Abstract}

Intracerebral malignant brain tumors remain one of the most complex problems of neuro-oncology. Today, promising results of the use of targeted drugs have been received, which determine the important diagnostic and predictive value of molecular genetic markers of glial and metastatic brain tumors.

Aim: The study of the prevalence of MGMT (O6-methylguanine-DNA methyltransferase) and PTEN (phosphatase and tensin homologue deleted on chromosome 10) gene expression by real time polymerase chain reaction in tumor tissue of gliomas and brain metastases. 
Materials and methods: From thirty patients were received tumor material (29 cases of glioma III-IV degree of anaplasia and one case of metastatic brain lesion of adenocarcinoma). The normalized expression of MGMT and PTEN genes was determined by real-time polymerase chain reaction.

Results: In all 30 (100\%) patients with tumor fragments, we determined normalized expression of MGMT and PTEN genes. In most cases, $53 \%$ of the observations (16 out of 30 patients) showed a low normalized expression of MGMT gene ( $<40$ c. u.) and a low normalized PTEN expression rate of $73 \%$ ( 22 out of 30 patients) ( $<40$ c. u.). The average expression level of the MGMT gene in the range from 40 to $100 \mathrm{c}$. u. (6/20\% of patients) was considered prognostic favourable for the response to temozolomide chemotherapy.

Conclusions: The study of $M G M T$ gene expression, a chemotherapy marker for temozolomide, indicates a trend toward correlation between expression levels and therapeutic efficacy. The study of the expression of the PTEN gene, the blocker of the PI3K/AKT signal pathway, indicates a different degree of expression of this enzyme in the tumour samples studied. The predictive value of the indicator for target therapy is appropriate in comparison with the EGFR mutation. Further profound analysis of the results is required with increasing number of sampling and observation period.

Keywords: malignant brain tumors, glioblastoma, $M G M T$ gene, $P T E N$ gene, EGFR, personalized medicine.

DOI: $10.21303 / 2504-5679.2019 .00949$

\section{Introduction}

Intracerebral malignant brain tumors, regardless of their genesis, primary or metastatic, remain the most painful and unresolved issue of neuro-oncology [1, 2]. Since the 70s of the last century, surgery along with radiotherapy (RT) remains the main methods of treating patients with malignant intracerebral tumors. The combination of these two treatments allowed doubling the survival rate $[3,4]$. The survival of patients with malignant gliomas progressed with the development of therapeutic protocols, especially in the introduction of the Stupp protocol of chemotherapy (CT) in 2005 in the clinical practice. According to the Stupp protocol, the temozolomide cytotoxic effect (TMZ) is added to the postoperative RT, followed by TMZ CT for six cycles. This allowed a two-year overall survival rate to be increased to $26.5 \%$ compared with only $10.4 \%$ for post-operative RT in mono-regimen [5]. It is known that TMZ CT in the complex treatment of patients with glioblastoma (GBM) in $39 \%$ of cases increases the average life expectancy of some categories of patients up to 24 months [6]. However, TMZ CT is also widely known, and is associated, first of all, with resistance to this drug. Despite the fact that TMZ CT has been used for more than ten years in the treatment of malignant glial tumors, the causes and mechanism of TMZ resistance development are not fully understood today and are the subject of scientific research $[7,8]$.

Independent risk factors associated with less long-term survival in malignant glial tumors are age of the patient ( $\geq 60$ years), non-radical tumour removal, low preoperative functional status of the patient (KPS $<70$ ), absence of post-operative RT and CT, reduction of postoperative TMZ CT $(<4$ years $)[10,11]$. In the case of a more favourable prognosis at the molecular level, the presence of methylation of the promoter of the $\mathrm{O}^{6}$-methylguanine gene of DNA-methyltransferase $(M G M T)$ or the presence of mutations in the isocyte dehydrogenase (IDH) gene (Hartmann et al. 2013; Reifenberger et al., 2014) may be indicated. It is with the differences in the molecular biology of the tumors that the same histotype tumors are different in their response to therapy. Therefore, in modern neuro-oncology of special diagnostic and prognostic significance acquire molecular genetic markers of tumors, as an essential component of the selection of treatment tactics [12].

The development of molecular biology and the orientation towards personalized medicine have led to a fundamentally new approach in the treatment of cancer patients with the use of molecular targeting drugs that block the proliferation of tumour cells by selective inhibition of its major signalling pathways - ligands, membrane receptors, intracellular proteins, etc. [6].

$\mathrm{CT}$ is an important component of the integrated therapy of cancer patients. Heterogeneity of tumors of one histotype according to the molecular mechanism of their development and mechanisms of chemo-resistance induced to personification of therapy. Today, along with tradition- 
al cytotoxic chemotherapy, targeted therapy is becoming increasingly important. The essence of the approach lies in the preliminary study of key genetic mutations that trigger uncontrolled cell proliferation and inhibition of apoptosis. Therefore, targeting therapy is based on the blocking of processes that are abnormally activated by mutation $[13,14]$.

When assigning cytostatics, it is important to determine the expression of the corresponding genes of chemoreceptor. Studies are conducted using biopsy or postoperative tumour tissue. Thus, the use of an antibacterial CT is based on the need for the prescription of chemotherapy, either traditional or targeted, from the standpoint of the current level of knowledge about molecular genetic prediction. The deepening of the search for molecular genetic markers, which allows predicting the effectiveness of therapy of intracerebral tumors, remains relevant in neuro-oncology.

\section{Aim of research}

The study of the prevalence of MGMT ( $\mathrm{O}^{6}$-methylguanine-DNA methyltransferase) and PTEN (phosphatase and tensin homologue deleted on chromosome 10) gene expression by real time polymerase chain reaction in glioma tumour tissue and brain metastases.

\section{Materials and methods}

The research was conducted at the State Institution "Institute of Neurosurgery named after A.P. Romodanova NAMS of Ukraine" (certificate on quality management is registered in the Register of Certification Systems of UkrSEPRO № UA.2.166/0909-15 dated June 10, 2015, valid until June 09, 2020), in the Department of Neurobiology (Certificate of Attestation No. PT-221/14 dated 04.07.2014 till 03.07.2019) which certifies that the department is certified on the basis of the Law of Ukraine "On Metrology and Metrological Activity", meets the criteria for attestation of measuring laboratories in accordance with the Rules of Authorization and Certification in the State Metrology System. The department is certified for carrying out measurements of the indicators of the objects according to the industry, which is given in the appendix to the certificate and is an integral part of it.

All patients included in the study were treated at the State Institution "Institute of Neurosurgery named after A.P. Romodanova NAMS of Ukraine".

The study included patients with different tumour brain lesions: both primary and metastatic. Surveyed and operated to obtain tumour material for further studies of 30 patients from 04.2017 to 09.2018: 1 case of anaplastic astrocytomas (AA); 26 cases of GBM IV grade anaplasia, of which 22 cases was first-time GBM diagnosis; 3 cases of continued growth (recurrent) GBM; 1 case of secondary GBM; 1 case of prolonged growth of anaplastic oligodendroglioma (AOG); 1 case of anaplastic ganglioglioma; 1 case of metastatic adenocarcinoma in the brain. Two of the 30 patients with GBM, were dropped out of observation, the observations of the remaining 28 patients are known.

All patients were informed about the conduct of research and informed consent to their implementation. The research was carried out in accordance with the ethical norms adopted by the Ukrainian legislation.

\section{Polymerase chain reaction (PCR) method in real time}

Material for the study was obtained from fragments of brain tumour tissue extracted during surgical intervention. Tissue immediately after sterile removal was treated as follows: the fragments of blood vessels and necrotized fragments were removed, the purified tissue was placed in sterile cryotubes and stored in liquid nitrogen at a temperature of $-196^{\circ} \mathrm{C}$ until the time of use in the experiment.

\section{Isolation of total RNA}

The total RNA was isolated from samples of tissues frozen in liquid nitrogen using the commercially available PureLink RNA Mini Kit Kit (Applied Biosystems, USA), respectively, 
the kit instructions. Selection steps consisted of lysis of cells, RNA binding to the membrane, purification of RNA and elution. Guanidine isothiocyanate is included in the prevention of degradation of RNA into the lysis and washing buffers. The isolated RNA was placed on ice, checked for quality and used immediately for the synthesis of cDNA in the reverse transcription reaction.

\section{Determination of the quality of the isolated RNA}

The absorption spectrum of the total RNA solution was roughly estimated by the degree of purification of RNA from proteins and guanidine. The ratio of $260 \mathrm{~nm} / 280 \mathrm{~nm}$ should be between 1.9 and 2.1. Samples that had lower or higher values were not included in the experiment. The RNA was evaluated by absorbance at $260 \mathrm{~nm}$ on a spectrophotometer.

\section{Synthesis of the first chain of cDNA}

The cDNA was obtained by kit of Tag Man reverse transcription reagents (Applied Biosystems, USA) using the reverse transcription reaction, respectively, with the kit instructions. The reaction was carried out in a volume of $20 \mu \mathrm{l}$. OligodT primers were used as primers.

Determination of the level of expression of genes by real-time PCR

The level of expression of MGMT (Hs01037698_m1) and PTEN (Hs02621230_s1) genes was analyzed on a real-time PCR fluorescence detection system of the SFX96 Touch (BioRad, USA) using Tag Man Universal PCR Master Mix (Applied Biosystems, USA) and Tag Man Gene Expression Assays (Applied Biosystems, USA) on the following protocol:

Primary denaturation $95^{\circ} \mathrm{C}-10$ minutes (1 cycle).

Amplification cycle $(\times 40)$ :

- denaturation $95^{\circ} \mathrm{C}-15 \mathrm{sec}$;

- annealing of primers, elongation and fixation of fluorescence signal $60{ }^{\circ} \mathrm{C}-1$ minute.

All reactions were carried out in separate test tubes. The volume of the reaction mixture was $20 \mu 1$.

To evaluate the reproducibility of the threshold cycle values, all samples with each pair of primers were amplified in double repetition. The difference between the samples was no more than 0.5 cycle.

Accumulation of amplification products was determined using oligonucleotide samples of the TagMan type (probes), complementary to the central portion of the amplified transcript fragment. The FAM is attached to the 5 'end of the probe, while the 3' end carries the MGB shield. Upon amplification of the transcript there is a separation of the fluorophore and the absorber and the device fixes the fluorescence signal. The oligonucleotide samples that were used to determine the expression of the genes studied are shown in Table $\mathbf{1 .}$

To check the absence of amplification of transcript regions of the genes studied on possible impurities of genomic DNA in the sample, parallel reactions of amplification of the RNA specimen without reverse transcription and cDNA were pre-performed.

Table 1

Nucleotide sequence of fluorescence probes used to determine the level of gene expression

\begin{tabular}{cc}
\hline Gene & Sequence of the oligonucleotide test \\
\hline$M G M T$ & 5'gcaancengnccccatcctcatccc 3' \\
$P T E N$ & 5 'atgctgcacagaaattttcaatttg3' \\
$G U S B$ & 5'gctactacttgaagatggtgatcgc3'
\end{tabular}

For the real time PCR method, the gene of glucuronidase GUSB (Hs00939627_m1), which belongs to the family of "housekeeping genes", has been selected as the reference 
gene for the gene reference $M G M T$ and PTEN, which is characterized by a stable expression level among various specimens. It is assumed that the change in the amount of its cDNA depends only on the influence of additional factors that determine the kinetics of reverse transcription. This allows comparing the level of gene expression between different samples.

The data analysis was performed at the threshold fluorescence, which is the main criterion for evaluating the results. It describes a certain cycle of PCR $(\mathrm{Ct})$, which shows a significant increase in fluorescence compared with the background level and begins the exponential phase of the PCR cycle.

The absolute number of copies of the mRNAs of the MGMT and PTEN genes in tumour samples was determined using the tenfold dilutions of a fragment of the MGMT gene enclosed in the plasmid and constructed on the basis of these data of the standard curve. GeneArt Gene Synthesis (Invitrogen, Thermo Fisher Scientific, Germany) was used for this purpose. The calculations used the equation of the curve $y=-0.3415 x+13.275$. The difference in the level of gene expression between the specimens was evaluated at the normalized number of copies of the mRNAs of the MGMT and PTEN genes relative to the number of copies of the housekeeping gene, GUSB.

\section{Results}

In all $30(100 \%)$ patients with tumour fragments, we determined normalized expression of $M G M T$ and PTEN genes. Table 2 presents the results of the determination of normalized expression of MGMT and PTEN genes in the tissue of glial tumour fragments and brain metastases extracted during surgical removal, further adjuvant treatment was traced. In 18 (69\%) of 26 patients with GBM, adjuvant radiotherapy (RT) was conducted with concomitant TMZ CT. In 14 (54\%) of 26 patients with GBM after completion of postoperative adjuvant RT, TMZ CT was performed.

In $16(53 \%)$ out of 30 examined patients, a low normalized expression of $M G M T$ gene ( $<40$ c. u.) was observed. In $6(20 \%)$ patients, this indicator was in the range of $40 \mathrm{c}$. u. to $100 \mathrm{c}$. u. The use of TMZ in such cases is considered appropriate and effective, as evidenced by overall survival (OS) in the study group of patients (Table 2).

In one case, in a patient with a recurrent GBM (observation No. 27, Table 2), the normalized expression of $M G M T$ gene significantly exceeded this indicator and amounted to 2,292.8 c. u. in the remaining patients, which is a prognostic negative factor. In this observation, the recurrence-free period (RFP) was 18 months, overall survival (OS) was 25 months; the patient died 7 months after the onset of relapse.

In the case of secondary GBM (observation № 25, Table 2), the normalized expression of the $M G M T$ gene was 10.3 c. u., RT was performed with concomitant TMZ CT, in the subsequent treatment of 6 courses of adjuvant TMZ CT. This patient is alive, the observation lasts 22 months.

In our observation group, in the majority of patients, a low normalized expression of the PTEN gene (<40 c. u.) was detected in $22(73 \%)$ cases. In the remaining $8(27 \%)$ patients, the normalized expression of the PTEN gene exceeded $40 \mathrm{c}$. u. and ranged from $61.6 \mathrm{c}$. u. to 21390.5 c. u. In this case, the correlation between normalized expression of PTEN gene and the survival rate of patients, nor the level of normalized expression of $M G M T$ gene has not been established. The highest normalized index of PTEN gene expression is $21390.5 \mathrm{c}$. u. was observed in a patient with GBM, which is still alive, is observed for 10 months, data for relapse of the tumour has not been received (observation № 196 Table 2). Two patients with GBM with high OS 22 months, who are still alive (observation № 1 and 8, Table 2), had the same normalized expression of PTEN gene $-0.001 \mathrm{c}$. u. At the same time, they differed in the level of expression of the gene $M G M T-3.1 \mathrm{c}$. u. and $22.5 \mathrm{c}$. u. in accordance. Both cases belong to a group that has a low normalized expression of $M G M T$ gene ( $<40 \mathrm{c}$. u.) and accounts for most observations $(53 \%)$. 
Table 2

Expression of MGMT and PTEN genes in the tissue of glial and metastatic brain tumor fragments in RT-treated patients using TMZ CT in concomitant and / or adjuvant regimens

\begin{tabular}{|c|c|c|c|c|c|c|c|c|c|c|c|c|c|}
\hline$\dot{8}$ & 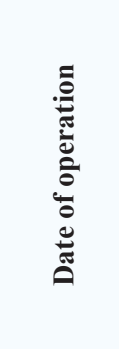 & ठ் & 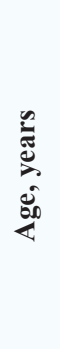 & 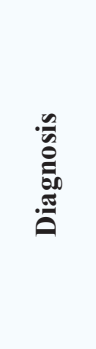 & 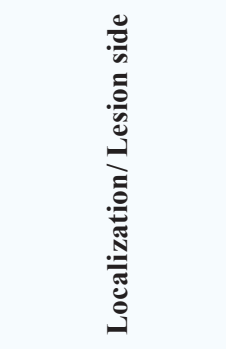 & 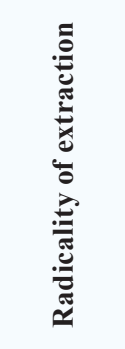 & 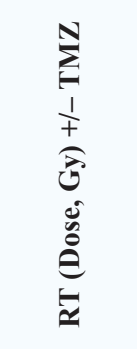 & 它 & 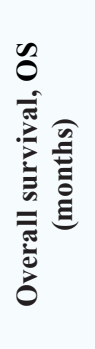 & 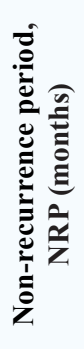 & 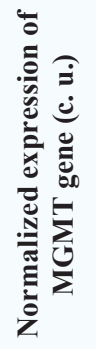 & 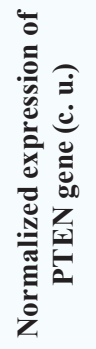 & 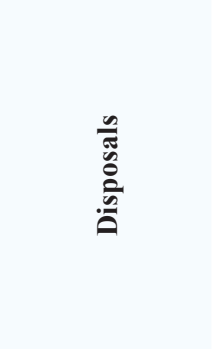 \\
\hline 1 & 2 & 3 & 4 & 5 & 6 & 7 & 8 & 9 & 10 & 11 & 12 & 13 & 14 \\
\hline 1 & 13.07.17 & male & 56 & GBM & $\begin{array}{c}\text { parieto-occipital/ } \\
\text { left }\end{array}$ & subtotal & $60+\mathrm{TMZ}$ & $\begin{array}{c}\text { TMZ } \\
6 \text { courses }\end{array}$ & 22 & 12 & 3.1 & 0.001 & $\begin{array}{l}\text { alive (radiosurd } \\
\text { gery } 07 / 2018 \text { ) }\end{array}$ \\
\hline 2 & 21.06 .18 & female & 48 & GBM & $\begin{array}{c}\text { frontoparietal/ } \\
\text { left }\end{array}$ & $\begin{array}{l}\text { frac- } \\
\text { tional }\end{array}$ & $60+\mathrm{TMZ}$ & $\begin{array}{c}\text { TMZ } \\
2 \text { courses }\end{array}$ & 11 & 11 & 3.3 & 0.1 & alive \\
\hline 3 & 13.06 .18 & female & 50 & GBM & $\begin{array}{l}\text { fronto-callous/ } \\
\text { right }\end{array}$ & $\begin{array}{l}\text { frac- } \\
\text { tional }\end{array}$ & $63+\mathrm{TMZ}$ & $\begin{array}{l}\text { CCNU } \\
1 \text { course }\end{array}$ & 11 & 11 & 7.3 & 0.2 & alive \\
\hline 4 & 27.07 .17 & female & 68 & GBM & $\begin{array}{l}\text { two side parietal- } \\
\text { callous }\end{array}$ & $\begin{array}{l}\text { frac- } \\
\text { tional }\end{array}$ & - & - & 9 & 6 & 13.5 & 61.6 & died \\
\hline 5 & 26.06 .17 & male & 39 & GBM & $\begin{array}{l}\text { posterior- } \\
\text { frontal/right }\end{array}$ & subtotal & $60+\mathrm{TMZ}$ & $\begin{array}{c}\text { TMZ } \\
3 \text { courses }\end{array}$ & 13 & 7 & 17.4 & 0.1 & died \\
\hline 6 & 04.07 .17 & female & 36 & GBM & $\begin{array}{c}\text { frontal-callous/ } \\
\text { left }\end{array}$ & $\begin{array}{l}\text { frac- } \\
\text { tional }\end{array}$ & $60+\mathrm{TMZ}$ & $\begin{array}{c}\text { TMZ } \\
3 \text { courses }\end{array}$ & 6 & 6 & 17.9 & 2.0 & $\begin{array}{l}\text { died as a result } \\
\text { of pulmonary } \\
\text { artery thrombo- } \\
\text { sis, death that } \\
\text { is not related to } \\
\text { the underlying } \\
\text { disease }\end{array}$ \\
\hline 7 & 08.08.18 & male & 80 & GBM & $\begin{array}{c}\text { temporoparietal/ } \\
\text { left }\end{array}$ & subtotal & $40+\mathrm{TMZ}$ & - & 9 & 3 & 19.8 & 0.3 & alive \\
\hline 8 & 27.07.17 & male & 64 & GBM & $\begin{array}{l}\text { subcortical } \\
\text { frontal/right }\end{array}$ & subtotal & $60+\mathrm{TMZ}$ & - & 22 & 15 & 22.5 & 0.001 & alive \\
\hline 9 & 18.12.17 & male & 56 & GBM & $\begin{array}{c}\text { corpus callosum/ } \\
\text { left }\end{array}$ & $\begin{array}{l}\text { frac- } \\
\text { tional }\end{array}$ & $60+\mathrm{TMZ}$ & $\begin{array}{c}\mathrm{TMZ} \\
6 \text { courses }\end{array}$ & 18 & 18 & 26.30 & 1.7 & alive \\
\hline 10 & 20.11.17 & male & 61 & GBM & $\begin{array}{c}\text { frontotemporal/ } \\
\text { left }\end{array}$ & $\begin{array}{l}\text { frac- } \\
\text { tional }\end{array}$ & - & - & - & - & 32.8 & 229.0 & $\begin{array}{l}\text { unknown } \\
\text { (the occupied } \\
\text { regions of the } \\
\text { Donetsk region) }\end{array}$ \\
\hline 11 & 05.07 .17 & male & 55 & GBM & $\begin{array}{l}\text { frontal medial/ } \\
\text { right }\end{array}$ & subtotal & $60+\mathrm{TMZ}$ & $\begin{array}{l}\text { CCNU } 5 \\
\text { courses }\end{array}$ & 22 & 22 & 39.6 & 1.3 & alive \\
\hline 12 & 03.04 .17 & male & 37 & GBM & $\begin{array}{l}\text { frontal medial } \\
\text { occipital/right }\end{array}$ & subtotal & $60+\mathrm{TMZ}$ & $\begin{array}{c}\text { TMZ } \\
6 \text { courses }\end{array}$ & 11 & 8 & 40.6 & 0.5 & died \\
\hline 13 & 30.05 .18 & male & 43 & GBM & temporal/right & total & $60+\mathrm{TMZ}$ & $\begin{array}{c}\text { TMZ } \\
3 \text { courses }\end{array}$ & 12 & 12 & 48.6 & 0.2 & alive \\
\hline 14 & 13.04 .17 & male & 53 & GBM & $\begin{array}{l}\text { frontotemporal/ } \\
\text { right }\end{array}$ & subtotal & $60+\mathrm{TMZ}$ & $\begin{array}{c}\text { TMZ } \\
5 \text { courses }\end{array}$ & 25 & 12 & 49.8 & 0.4 & alive \\
\hline 15 & 12.04.17 & male & 40 & GBM & frontal/right & $\begin{array}{l}\text { subtotal- } \\
\text { frac- } \\
\text { tional }\end{array}$ & $60+\mathrm{TMZ}$ & $\begin{array}{c}\text { TMZ } \\
6 \text { courses }\end{array}$ & 25 & 17 & 70.4 & 1.45 & alive \\
\hline 16 & 18.12 .17 & male & 47 & GBM & temporal/right & total & 60-TMZ & $\begin{array}{c}\text { TMZ } \\
3 \text { courses }\end{array}$ & 17 & 17 & 89.8 & 259.7 & alive \\
\hline
\end{tabular}


Continuation of Table 2

\begin{tabular}{|c|c|c|c|c|c|c|c|c|c|c|c|c|c|}
\hline 1 & 2 & 3 & 4 & 5 & 6 & 7 & 8 & 9 & 10 & 11 & 12 & 13 & 14 \\
\hline 17 & 20.06 .18 & male & 70 & GBM & $\begin{array}{c}\text { frontal medial/ } \\
\text { right }\end{array}$ & subtotal & $60+\mathrm{TMZ}$ & $\begin{array}{c}\text { TMZ } \\
2 \text { courses }\end{array}$ & 11 & 11 & 90.5 & 24.6 & alive \\
\hline 18 & 12.12 .17 & female & 37 & GBM & frontal/left & total & - & - & - & - & 105.9 & 2747 & unknown \\
\hline 19 & 30.07 .18 & female & 49 & GBM & $\begin{array}{c}\text { frontal medial/ } \\
\text { right }\end{array}$ & subtotal & $60+\mathrm{TMZ}$ & - & 10 & 10 & 118.3 & 21390.5 & alive \\
\hline 20 & 27.11.17 & male & 67 & GBM & $\begin{array}{c}\text { frontotemporal } \\
\text { parietal/right }\end{array}$ & subtotal & 60-TMZ & - & 18 & 5 & 125.6 & 651.6 & alive \\
\hline 21 & 23.04 .18 & female & 62 & GBM & $\begin{array}{c}\text { partial temporal } \\
\text { subcortical/left }\end{array}$ & subtotal & $60+\mathrm{TMZ}$ & $\begin{array}{c}\text { TMZ } \\
4 \text { courses }\end{array}$ & 13 & 13 & 192.6 & 13.1 & alive \\
\hline 22 & 27.04 .17 & female & 66 & GBM & temple/right & total & $60+\mathrm{TMZ}$ & $\begin{array}{c}\text { TMZ } \\
3 \text { courses }\end{array}$ & 13 & 12 & 251.6 & 2.7 & died \\
\hline 23 & 13.06 .18 & female & 65 & $\begin{array}{l}\text { GBM with } \\
\text { oligoden- } \\
\text { droglial } \\
\text { component }\end{array}$ & $\begin{array}{c}\text { temporal } \\
\text { subcortical/left }\end{array}$ & $\begin{array}{l}\text { frac- } \\
\text { tional }\end{array}$ & - & - & - & - & 9.0 & 0.8 & $\begin{array}{l}\text { died in the } \\
\text { postoperative } \\
\text { period, RT and } \\
\text { ACT were not } \\
\text { conducted }\end{array}$ \\
\hline 24 & 29.06 .17 & male & 52 & AA & $\begin{array}{c}\text { frontotemporal/ } \\
\text { right }\end{array}$ & subtotal & - & - & - & - & 125.0 & 8.6 & $\begin{array}{l}\text { died in the } \\
\text { postoperative } \\
\text { period, RT and } \\
\text { ACT were not } \\
\text { conducted }\end{array}$ \\
\hline 25 & 24.07 .17 & female & 50 & $\begin{array}{l}\text { secondary } \\
\text { GBM }\end{array}$ & frontal/right & total & $60+\mathrm{TMZ}$ & $\begin{array}{c}\text { TMZ } \\
6 \text { courses }\end{array}$ & 22 & 22 & 10.3 & 0.2 & alive \\
\hline 26 & $11.05 .18^{*}$ & male & 52 & $\begin{array}{l}\text { cont. } \\
\text { growth. } \\
\text { GBM }\end{array}$ & temple/right & total & - & - & $5^{* *}$ & $5^{* *}$ & 20.5 & 390.8 & died \\
\hline 27 & $26.02 .18^{*}$ & female & 58 & $\begin{array}{l}\text { cont. } \\
\text { growth. } \\
\text { GBM }\end{array}$ & temple/left & $\begin{array}{l}\text { frac- } \\
\text { tional }\end{array}$ & - & - & $7^{* *}$ & $7^{* *}$ & 2292.8 & 164.6 & $\begin{array}{l}\text { died (RFP after } \\
\text { the first opera- } \\
\text { tion } 18 \text { months) }\end{array}$ \\
\hline 28 & $02.04 .18^{*}$ & female & 42 & $\begin{array}{l}\text { cont. } \\
\text { growth. } \\
\text { (AOD) }\end{array}$ & temple/right & total & 60-TMZ & PCV & 13 & 13 & 205.1 & 9.6 & alive \\
\hline 29 & 30.05 .18 & female & 62 & $\begin{array}{l}\text { Adeno- } \\
\text { carcinoma } \\
\text { metastasis }\end{array}$ & sincipital/right & total & 60-TMZ & $\mathrm{CCNU}$ & 12 & 12 & 5.3 & 0.001 & alive \\
\hline 30 & 14.09 .18 & female & 43 & $\begin{array}{l}\text { Anaplastic } \\
\text { gangliogli- } \\
\text { oma }\end{array}$ & $\begin{array}{l}\text { parietomedial/ } \\
\text { right }\end{array}$ & $\begin{array}{l}\text { frac- } \\
\text { tional }\end{array}$ & 60-TMZ & PCV & 8 & 8 & 6.8 & 0.1 & alive \\
\hline
\end{tabular}

Note: * - date of surgery for tumour recurrence (re-operation); ** - survival in the post recessional period; $M G M T\left(O^{6}\right.$-methylguanine-DNA-methyltransferase); PTEN (phosphatase and tensin homologue deleted on chromosome 10); RT (radiotherapy); CT (chemotherapy); TMZ (temozolomide); OS (overall survival); RFP (recurrence-free period); ACT (adjuvant chemotherapy); CCNU (lombustine); Dose, Gy-total dose of RT in Gray

\section{Discussion}

As a result of our work, the prevalence of expression of MGMT and PTEN genes by real-time PCR in glandular tumor tissue and brain metastases has been studied. In all 30 (100\%) patients with tumor fragments, we determined normalized expression of MGMT and PTEN genes. In most cases, $53 \%$ of the observations (16 out of 30 patients) showed a low normalized expression of $M G M T$ gene (<40 c. u.) and a low normalized expression of PTEN gene $-73 \%$ (22 out of 30 patients) ( $<40 \mathrm{c}$. u.). In this case, correlation of normalized expression of PTEN gene with survival of patients and level of normalized expression of $M G M T$ gene has not been established. In 6 (20\%) patients, normalized expression of the gene $M G M T$ varied in the range of $40 \mathrm{c}$. u. up to $100 \mathrm{c}$. u. Such cases were considered prognostic favorable for the response to TMZ CT, which is confirmed 
by survival rates in the study group. Our results indicate a correlation between the level of expression of the MGMT gene and the efficacy of TMZ CT.

Unfortunately, in our work, due to the small sample size, we were unable to analyze the statistical significance of the results obtained, as well as to estimate the predictive significance of the expressions of the MGMT gene and the PTEN gene. This is a weak link in our study and requires further analysis of the results with an increase in the number of samples and the period of observation.

It would also be interesting to investigate the mutations in the EGFR gene (epidermal growth factor receptor, ErbB-1) in the samples presented, the correlation of this mutation with the level of expression of the PTEN gene, and to analyze their prognostic value for assessing the effectiveness of $E G F R$ targeting therapy in neuro-oncology patients.

Thus, there is a need to continue such a study, deepen the analysis and implement the results in clinical practice.

The subject of our research is relevant in neuro-oncology and corresponds to the demands of modern scientific research. To date, molecular biology has identified several genetic loci in the human genome, whose functioning determines the effectiveness of antitumor effects of CT and RT. Deepening understanding of the molecular-biological properties of brain tumors leads to the expansion of therapeutic options, primarily targeted therapy. In recent years, the number of publications devoted precisely to the clinical aspects of molecular biology has increased.

Yes, Brandes A.A. and co-authors (2017) studied the role of MGMT methylation status at various stages of GBM pathomorphism. It has been determined that one of the key factors to be taken into account when treating malignant glioma is the functioning of the gene of the reparative enzyme $M G M T$. The gene of the reagent enzyme, $M G M T$, rapidly resumes damage to the DNA of cells by glioma (and all other proliferating cells of the patient's body) after the effects of the alkylating agent. The presence of $M G M T$ gene expression depends on the functioning of other genes (for example, DNA gene promoter of methylation), some gene ensembles that affect apoptotic processes, etc. [15].

Published in 2018, the work of Nguyen, H. S., and co-authors is devoted to the study of molecular markers of resistant GBM and ways to overcome therapeutic resistance [16]. The authors emphasize that the study of expression of the gene $M G M T$, a product that reduces the effectiveness of alkylating cytostatics, is necessary for the administration of TMZ CT.

The main modern trend in neuro-oncology is the person-oriented approach in the appointment of antibacterial chemotherapies. First of all, this is due to the heterogeneity of the tumors of one histotype by the molecular mechanism of their development and mechanisms of chemo-resistance. The basis of targeted therapy, unlike traditional cytotoxic chemotherapy, is the blocking of processes that are abnormally activated due to mutations.

In the cells of many tumors, EGFR abnormal receptors are detected as a consequence of the mutation of this gene. In cells with mutation activation of the signaling pathway of EGFR occurs, which, in turn, initiates the processes of malignant transformation in most tumors. The presence of gene mutations in the EGFR allows the selection of a group of patients who may have a positive response to the inhibitor of the tyrosine kinase of the epidermal factor receptor. The work of Kwatra M. M. and co-authors (2017) is devoted to the analysis of EGFR targeting GBM therapy [17]. The EGFR transmembrane receptor binds to extracellular ligands belongs to the family of transmembrane receptors: EGFR (ErbB-1), HER 2 / c-neu (ErbB-2), Her 3 (ErbB-3) and Her 4 (ErbB-4), the intracellular part of which exhibits tyrosine kinase activity. The amplification of the EGFR gene is found at $60 \% \mathrm{GBM}$, in the half of GBM, hyperfragmentation of EGFR is observed. Studies with blockers and antibodies to EGFR (Erlotinib, Gefitinib, Nimotuzumab) are currently ongoing and require more advanced scientific research [17, 18].

Eskilsson E. and co-authors in 2018 presented a work concerned with EGFR heterogeneity GBM and therapeutic aspects of this problem. Such studies provide an opportunity for the proper administration of a specific inhibitor of tyrosine kinase - erlotinib and hefitinib [19].

Elsamadicy A. A. and co-authors (2017) show positive results of the use of the EGFR vIII (Rindopepimut (CDX-110)) protein in the vaccine against line I therapy in patients who did not receive TMZ. At this time, a separate type of EGFR-EGFR variation-EGFR version III mutation, which occurs in $20 \%$ GBM, is highlighted. It should be emphasized that the best results in this study were obtained in patients with unmethylated MGMT [20]. 
Recent studies have shown the expediency of molecular genetic prediction of the effectiveness of target-therapy of the brain tumors with the detection of mutations in the gene of EGFR (abnormal splicing and mutations in 18-21 exons, only 19 mutations) and expression of the PTEN gene. Recent work has been published that thoroughly the role of the PTEN protein in neuro-oncogenesis has been determined. In articles by Kang Y. J. and Benitez J. A., the molecular-biological significance of the PTEN protein and mutations in the PTEN gene [21, 22] is analyzed in detail. The PTEN protein encoded by the PTEN gene plays a role in the regulation of the cell cycle, is a tumor suppressor and functions as phosphatase. The main function of PTEN is the inhibition of the signal path controlled by phosphoinositol-3-kinase - one of the main pathways responsible for proliferation and cell survival. PTEN is part of a signaling pathway that stops cell division and induces apoptosis. Apoptosis is that of uncontrolled cell growth and progression of the oncological process. With malignant transformation, the cells accumulate mutations that ensure the progression of tumors. Mutations in the PTEN gene lead to the development of many tumors. The genetic inactivation of PTEN is indicated for GBM, uterine cancer, prostate cancer, and a decrease in PTEN activity is observed in lung cancer, breast cancer, and others.

In 2014, a meta-analysis was conducted on the study of the PTEN gene and its predictive value in gliomas [14]. It has been shown that the PTEN gene study is needed to evaluate the efficacy of EGFR targeting therapy, which is one of the few negative PI3K/AKT/mTOR signaling pathways and plays an important role in cellular proliferation, apoptosis and tumor invasion regulation. The sensitivity to therapy of brain tumors with EGFR inhibitors is significantly higher when coexpressed by the EGFRvIII oncogene and the PTEN tumor suppressor. In this case, the loss or mutations of the PTEN gene make the tumor resistant to EGFR inhibitors, as the PI3K/AKT/mTOR signaling pathway is not excluded. It has been established that a decrease in PTEN expression is a negative predictive marker for GBM survival, as well as a therapy response marker.

All this confirms the relevance of our research and the feasibility of further scientific research, aimed at studying the molecular genetic features of intracerebral tumors.

The authors report that there is no conflict of interest.

\section{Conclusions}

1. A study of MGMT gene expression, a marker of temozolomide chemotherapy sensitivity, indicates a trend towards correlation between expression levels and therapeutic efficacy. To determine statistically significant prognostic effects and informativeness of MGMT expression, it is necessary to expand the statistical sample and further studies with a larger number and observation period.

2. A study of the expression of the PTEN gene, the PI3K/AKT signalling pathway blocker, indicates a different degree of expression of this enzyme in the tumour samples studied. The predictive value of this indicator for targeting chemotherapy is possible in comparison with the EGFR mutation in these tumour tissue samples.

3. The study of molecular biological characteristics of intracerebral tumors and the implementation of these data in clinical practice provides the opportunity to develop more effective therapeutic protocols based on a personified approach to the treatment of neuro-oncology patients.

\section{References}

[1] Nørøxe, D. S., Poulsen, H. S., Lassen, U. (2016). Hallmarks of glioblastoma: a systematic review. ESMO Open, 1 (6), e000144. doi: http://doi.org/10.1136/esmoopen-2016-000144

[2] Wick, W., Osswald, M., Wick, A., Winkler, F. (2018). Treatment of glioblastoma in adults. Therapeutic Advances in Neurological Disorders, 11. doi: http://doi.org/10.1177/1756286418790452

[3] Walker, M. D., Alexander, E., Hunt, W. E., MacCarty, C. S., Mahaley, M. S., Mealey, J. et. al. (1978). Evaluation of BCNU and/ or radiotherapy in the treatment of anaplastic gliomas. Journal of Neurosurgery, 49 (3), 333-343. doi: http://doi.org/10.3171/ jns.1978.49.3.0333

[4] Walker, M. D., Green, S. B., Byar, D. P., Alexander, E., Batzdorf, U., Brooks, W. H. et. al. (1980). Randomized Comparisons of Radiotherapy and Nitrosoureas for the Treatment of Malignant Glioma after Surgery. New England Journal of Medicine, 303 (23), 1323-1329. doi: http://doi.org/10.1056/nejm198012043032303 
[5] Stupp, R., Mason, W. P., van den Bent, M. J., Weller, M., Fisher, B., Taphoorn, M. J. B. et. al. (2005). Radiotherapy plus Concomitant and Adjuvant Temozolomide for Glioblastoma. New England Journal of Medicine, 352 (10), 987-996. doi: http:// doi.org/10.1056/nejmoa043330

[6] Holland, E., Ene, C. (2015). Personalized Medicine for Gliomas. Surgical Neurology International, 6 (2), 89-95. doi: http:// doi.org/10.4103/2152-7806.151351

[7] Jiapaer, S., Furuta, T., Tanaka, S., Kitabayashi, T., Nakada, M. (2018). Potential Strategies Overcoming the Temozolomide Resistance for Glioblastoma. Neurologia Medico-Chirurgica, 58 (10), 405-421. doi: http://doi.org/10.2176/nmc.ra.2018-0141

[8] Lee, S. Y. (2016). Temozolomide resistance in glioblastoma multiforme. Genes \& Diseases, 3 (3), 198-210. doi: http://doi.org/ 10.1016/j.gendis.2016.04.007

[9] Wang, J., Hu, G., Quan, X. (2019). Analysis of the factors affecting the prognosis of glioma patients. Open Medicine, 14 (1), 331-335. doi: http://doi.org/10.1515/med-2019-0031

[10] Hartmann, C., Hentschel, B., Simon, M., Westphal, M., Schackert, G. et. al. (2013). Long-Term Survival in Primary Glioblastoma With Versus Without Isocitrate Dehydrogenase Mutations. Clinical Cancer Research, 19 (18), 5146-5157. doi: http:// doi.org/10.1158/1078-0432.ccr-13-0017

[11] Reifenberger, G., Weber, R. G., Riehmer, V., Kaulich, K., Willscher, E. et. al. (2014). Molecular characterization of long-term survivors of glioblastoma using genome- and transcriptome-wide profiling. International Journal of Cancer, 135 (8), $1822-$ 1831. doi: http://doi.org/10.1002/ijc.28836

[12] Louis, D. N., Perry, A., Reifenberger, G., von Deimling, A., Figarella-Branger, D., Cavenee, W. K. et. al. (2016). The 2016 World Health Organization Classification of Tumors of the Central Nervous System: a summary. Acta Neuropathologica, 131 (6), 803-820. doi: http://doi.org/10.1007/s00401-016-1545-1

[13] Medina, T. M., Lewis, K. D. (2016). The evolution of combined molecular targeted therapies to advance the therapeutic efficacy in melanoma: a highlight of vemurafenib and cobimetinib. OncoTargets and Therapy, 9, 3739-3752. doi: http:// doi.org/10.2147/ott.s86774

[14] Xiao, W.-Z., Han, D.-H., Wang, F., Wang, Y.-Q., Zhu, Y.-H., Wu, Y.-F. et. al. (2014). Relationships between PTEN gene mutations and prognosis in glioma: a meta-analysis. Tumor Biology, 35 (7), 6687-6693. doi: http://doi.org/10.1007/s13277-014-1885-1

[15] Brandes, A. A., Franceschi, E., Paccapelo, A., Tallini, G., De Biase, D., Ghimenton, C. et. al. (2017). Role of MGMT Methylation Status at Time of Diagnosis and Recurrence for Patients with Glioblastoma: Clinical Implications. The Oncologist, 22 (4), 432-437. doi: http://doi.org/10.1634/theoncologist.2016-0254

[16] Nguyen, H., Shabani, S., Awad, A., Kaushal, M., Doan, N. (2018). Molecular Markers of Therapy-Resistant Glioblastoma and Potential Strategy to Combat Resistance. International Journal of Molecular Sciences, 19 (6), 1765. doi: http://doi.org/10.3390/ ijms19061765

[17] Kwatra, M. (2017). A Rational Approach to Target the Epidermal Growth Factor Receptor in Glioblastoma. Current Cancer Drug Targets, 17 (3), 290-296. doi: http://doi.org/10.2174/1568009616666161227091522

[18] Liu, F., Mischel, P. S. (2017). Targeting epidermal growth factor receptor co-dependent signaling pathways in glioblastoma. Wiley Interdisciplinary Reviews: Systems Biology and Medicine, 10 (1), e1398. doi: http://doi.org/10.1002/wsbm.1398

[19] Eskilsson, E., Røsland, G. V., Solecki, G., Wang, Q., Harter, P. N., Graziani, G. et. al. (2017). EGFR heterogeneity and implications for therapeutic intervention in glioblastoma. Neuro-Oncology, 20 (6), 743-752. doi: http://doi.org/10.1093/neuonc/nox191

[20] Elsamadicy, A. A., Chongsathidkiet, P., Desai, R., Woroniecka, K., Farber, S. H., Fecci, P. E., Sampson, J. H. (2017). Prospect of rindopepimut in the treatment of glioblastoma. Expert Opinion on Biological Therapy, 17 (4), 507-513. doi: http://doi.org/1 0.1080/14712598.2017.1299705

[21] Benitez, J. A., Ma, J., D’Antonio, M., Boyer, A., Camargo, M. F., Zanca, C. et. al. (2017). PTEN regulates glioblastoma oncogenesis through chromatin-associated complexes of DAXX and histone H3.3. Nature Communications, 8 (1). doi: http:// doi.org/10.1038/ncomms15223

[22] Kang, Y.-J., Balter, B., Csizmadia, E., Haas, B., Sharma, H., Bronson, R., Yan, C. T. (2017). Erratum: Corrigendum: Contribution of classical end-joining to PTEN inactivation in p53-mediated glioblastoma formation and drug-resistant survival. Nature Communications, 8 (1). doi: http://doi.org/10.1038/ncomms15795 